\title{
Faculty Internship: Providing New Skills for Construction Educators
}

\section{Dr. Lisa M Holliday P.E., University of Oklahoma}

Prof. Matthew Reyes, University of Oklahoma

Matthew received his bachelor's and master's degrees from Texas A\&M University. After working for several years in the construction industry both in the field and in management, he joined the Construction Science faculty at the University of Oklahoma in 2012. Along with his research interests in earthen construction and the Latino workforce in construction, he is interested in teaching students to improve their visuo-spatial skills and abilities.

Prof. Kenneth F. Robson, University of Oklahoma 


\title{
The Associated General Contractors of America (AGC) Faculty Internship: Providing New Skills for Construction Educators
}

\author{
Lisa Holliday, Kenneth Robson, Matthew Reyes \\ University of Oklahoma \\ Norman, Oklahoma
}

Undergraduate Construction Management programs value both advanced education and construction experience in faculty. As more construction programs require faculty to hold a PhD, it is becoming increasingly difficult to find quality tenure-track faculty applicants with both a $\mathrm{PhD}$ and industry experience. Generally, the path to a $\mathrm{PhD}$ does not leave room for significant construction industry experience. The shortest path to a $\mathrm{PhD}$ is continuous education from undergraduate through graduate school. Once a person leaves the education path and enters industry, it is often hard to leave industry for full-time studies and construction does not lend itself to part-time graduate studies while working full-time. These divergent paths to a professional career leave a gap in prospective construction educators.

The Associated General Contractors of America (AGC) values construction experience in construction management faculty and has sponsored summer internships to increase faculty industry experience. The internship program is structured by a three party agreement between AGC, the sponsoring university, and a local contractor. Each of the three parties pays a third of the faculty intern's regular monthly salary. Thus, each entity has a vested interest in the faculty intern's success in the program and its benefits to education.

The University of Oklahoma took this opportunity to partner with a local general contractor to increase faculty construction experience and to train the faculty member in the use of Revit Structure. The faculty intern joined the contractor's pre-construction team and developed the Revit model for an upcoming project. The model was used by the contractor for their planning purposes. This additional Revit expertise will be integrated into the structures and documents classes. Through this industry experience and training, the faculty intern will bring construction knowledge and real world examples from industry back to the classroom to enhance learning.

Keywords: faculty internship, industry experience, faculty education, AGC

\section{Background}

Construction Science programs have traditionally valued industry experience among faculty. In the past, construction management programs treated the master's degree as a terminal degree and placed a high value on construction industry experience when seeking tenure-track faculty. ${ }^{6,7}$ That standard has changed and it is now growing increasingly important that construction faculty have a $\mathrm{PhD}$. Most tenure-track faculty position listings today require a $\mathrm{PhD}$ in Construction Science or a related field. For example, of the 17 tenure track faculty positions listed on the 
Associated Schools of Construction (ASC) employment listings, 16 require a $\mathrm{PhD}$ and a $\mathrm{PhD}$ is preferred on the final listing. ${ }^{3}$ Many of the job candidates that hold a PhD do not have construction industry experience but still have potential as educators while many candidates with industry experience are missing the $\mathrm{PhD}$ component. Often universities are forced to hire faculty with little or no relevant construction experience due to the $\mathrm{PhD}$ requirements.

The attainment of a $\mathrm{PhD}$ has grown as a requirement as research and external funding for has become more important. The essential aspect of industry experience is a result of the applied science nature of construction management education. ${ }^{6}$ The importance is reflected not only in job postings but also in accrediting body requirements. Both the Accreditation Board for Engineering and Technology (ABET) and the American Council for Construction Education (ACCE) note that faculty in construction engineering and construction engineering programs should have relevant professional experience. ${ }^{1,2}$ In fact, ABET considers this one of the ways in which faculty demonstrate their competence. ${ }^{1}$

This current demand on faculty for both a $\mathrm{PhD}$ and industry experience is not a pair of requirements that always complement one another. For example, the most direct path to a $\mathrm{PhD}$ is to pursue a master's degree directly after a bachelor's degree and then to pursue a $\mathrm{PhD}$ directly after a master's degree. There are several disadvantages for deviating from this direct path. If a student is away from school for a few years the codes, standards, and even computer programs change leading to the student finding himself or herself out-of-date. The additional challenge of re-acclimating to student life and making the change from an industry salary to student salary and tuition responsibilities can be a deterrent to someone making the shift from industry professional to student. All of these factors work against the transferring back and forth between education and industry in the pursuit of either a master's degree or a $\mathrm{PhD}$.

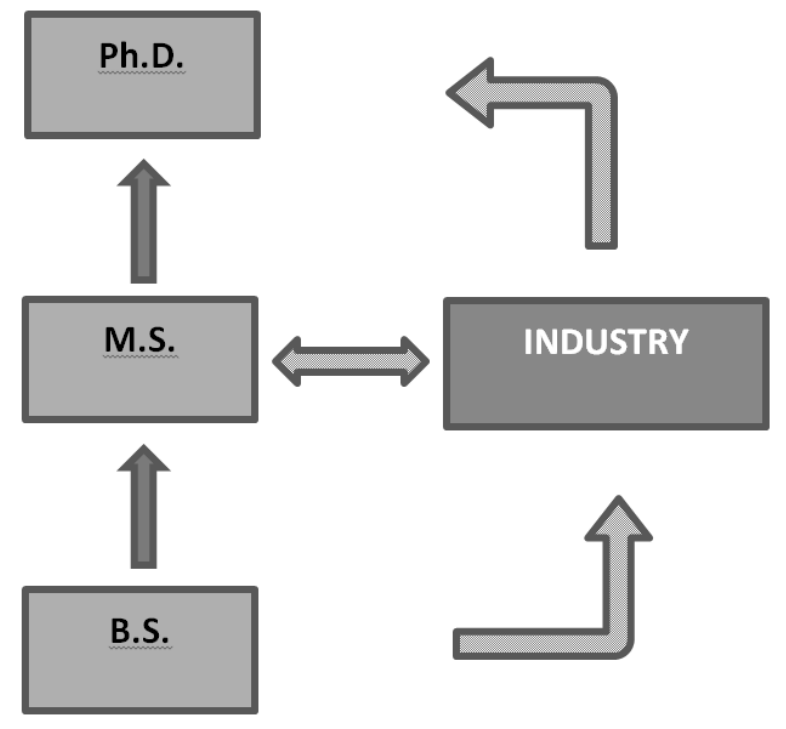

Figure 1: Paths to obtaining both a $\mathrm{PhD}$ and relevant industry experience 
The quality of industry experience is also relevant. The experience must be in construction management to be considered relevant and US schools prefer US industry experience. Assuming faculty have the desired education, some specialized construction experience can be gained during the summer months.

\section{Faculty Internship Program}

Faculty internships are not new to the construction industry. Construction programs have been sponsoring faculty internships for some time. For example, in 2004 the National Demolition Association sponsored a faculty internship with the goal of introducing demolition skills into the program at Purdue University. ${ }^{8}$ In 2000, Toni Hynds described the faculty internships as a "Win/Win Outcome." 5 This win/win is based on the idea that both faculty and industry gain education during the internship. Hynds describes the faculty internship win/win outcomes as an exchange between faculty and industry of new ideas, best practices, theory, and practical applications.

To help alleviate the shortage of industry experience among faculty and improve construction education the Associated General Contractors of America (AGC) has implemented the Faculty Internship Program (FIP). The AGC considers this program an important investment and they state, "Participating in this program is an investment in the future of the construction industry, providing valuable and current professional experience that can be shared in the classroom. Professional internships also benefit the host company by providing quality temporary help on projects and, if desired, feedback on management processes.” 3

To ensure the program started smoothly, the AGC conducted a pilot phase. The AGC FIP finished the second year of its pilot phase and is now implementing the full program and accepting applicants for the summer of 2013. The FIP is a partnership between AGC Foundation, AGC contractors, and Universities. The three involved parties each pay a third of the faculty member's salary for the duration of the internship, which can be 1-3 months. Each partner contributing to the cost ensures everyone has buy-in and is committed to the success of the internship.

\section{Intern and the Internship}

The AGC Faculty Internship Program requires that applicants identify a specific skill they seek to improve, learn or develop during the faculty internship. The construction science program at the University of Oklahoma (OU) used this opportunity to bring not only industry experience back to the program, but also to bring new technical skills into the Program. The construction science program at OU has required their students learn Building Information Modeling (BIM) computer skills such as Revit and AutoCAD for quite some time. The Construction Science program wanted to reinforce these skills among students by inserting BIM assignments throughout the curriculum but this requires more faculty members to become familiar with BIM software. For example, Revit is a program that is taught early in the coursework and then left dormant until the senior year. OU wanted to ensure students keep using BIM programs throughout their studies by introducing it into the structures sequence. The Faculty Internship 
Program was an opportunity to gain construction experience and computer training in Revit Structure situated in the context of a construction project.

The faculty member that took part in the pilot program joined the faculty without experience in construction management. The faculty member teaches structures courses and did have structural design and estimating experience, but little in the way of on the job construction experience. The previous summer (2011) the faculty intern (Lisa Holliday) spent the summer learning general construction knowledge at JE Dunn Construction Company in Oklahoma City, Oklahoma; this was not part of the AGC Faculty Internship Program. The intern spent the summer working on preconstruction services for a project called Four Partners Project (4PP). During the summer of 2012, 4PP was still under construction so it seemed a good fit for the faculty intern to return to the same job-site and help with the final phases of the project. The Revit Structure model for 4PP was already completed but the team was gearing up for their next project and it was proposed that the faculty intern would help create the Revit model of the structure.

\section{Pilot Program at the University of Oklahoma}

The summer objective was two-fold. The first objective was to gain general construction experience and bring real life construction examples and experiences into the construction science structures sequence. During the internship, the intern worked at the JE Dunn Construction job-site trailer at the 4PP Project located on the campus of OU. The intern worked directly under the Project Manager and had direct daily access to their BIM Specialist. This required a generous time commitment from JE Dunn. During the faculty intern's time at JE Dunn, 4PP was nearing substantial completion, and a new project, the Radar Innovations Lab at the University of Oklahoma (RIL), was recently awarded. This gave the faculty intern a chance to see both a project beginning and a project ending. The faculty intern not only experienced preconstruction services, but also the work leading up to the end of a project such as commissioning and close-out. The faculty intern helped with pre-construction services on the RIL project. Pre-construction tasks included reviewing and comparing construction drawings at different stages of completion, writing scopes of work, and getting estimates on specialty items.

The second objective was to gain experience with BIM in construction and more specifically the Autodesk program Revit Structure. Through the summer, the faculty intern worked on creating a computer model of the RIL structure. JE Dunn employees gave the faculty intern Revit Structure lessons and the faculty intern began the task of creating a model of the structure from the construction documents. The faculty intern worked daily to create the model beginning with the grid system, adding piers and grade beams, then slabs on the piers, adding the structural steel system, and then the floor and roof decks. This internship lasted for a total of two months during the summer of 2012.

Clearly defining the work that the faculty intern would accomplish over the summer contributed to the success of the internship. It was established early that the faculty intern would not follow the track of standard student interns at the company but instead would focus on learning BIM. Without this clear understanding of the goals and the skills to be learned, the faculty internship might have suffered from a lack of a clear understanding of the expected outcomes. 


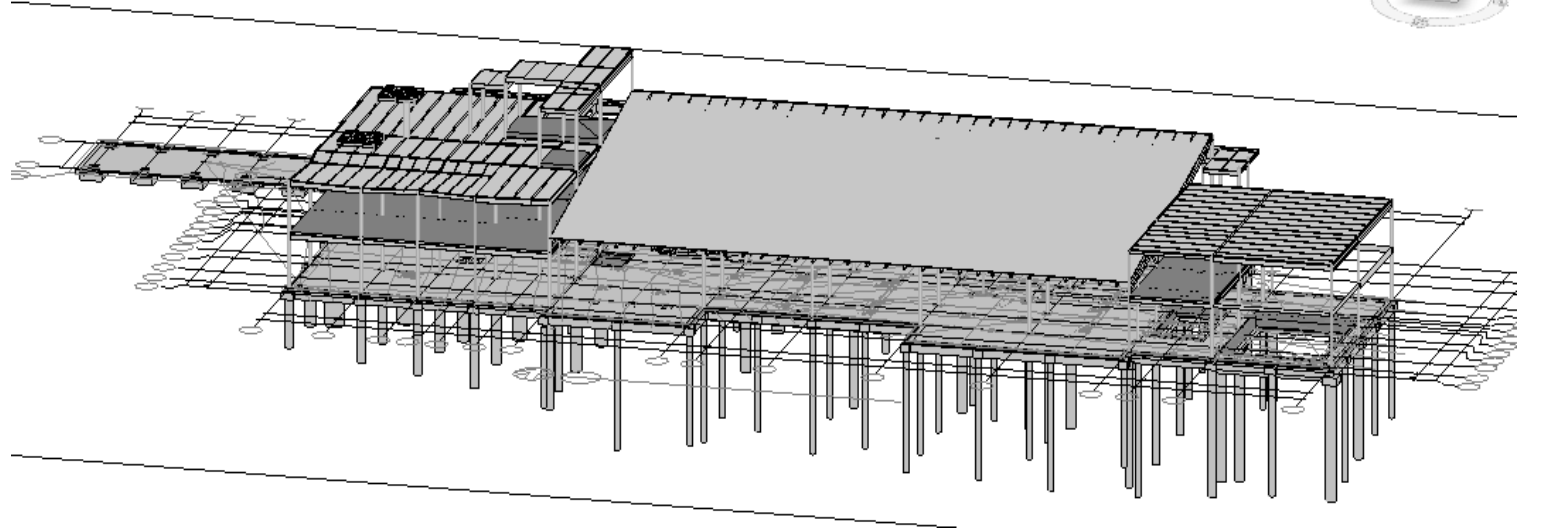

Figure 2: Revit structure model created as part of the faculty internship

\section{Learning Outcomes}

This BIM training is used directly in the construction classes at OU. First, in the Construction Documents Class and the accompanying laboratory session the students use Revit Structure to build a computer model based on a sample set of construction documents. They model a mockup wall based on the materials and specifications found in the documents and then physically build the mock-up wall from the details of the model. The faculty intern relied upon expertise gained during the internship for the implementation of Revit Structure in the classroom. She is able to instruct students in basic and intermediate level Revit skills and has begun requiring its use in the structures course sequence. The faculty member is able to demonstrate threedimensional computer models that explain structural concepts and requires that the students use Revit Structure during their homework assignments. This reiterates the use of Revit students learned in previous classes and situates the use of Revit in a new context, reinforcing the concept for more meaningful learning.

The construction experience is also full of important lessons that have been brought back to the classroom. During the final stages of a project was an interesting time to office in the jobsite trailer. It became evident that some sub-contractors were not going to be able to fulfill their contractual obligations. The conversations with those sub-contractors were always frank and sometimes confrontational. One of the lessons the faculty intern learned is that construction can sometimes require confrontation and future project managers should be ready for these situations. In addition, the faculty member also has many real life construction examples to use in classes and a relationship with construction professionals in the area.

\section{Conclusions}

The internship benefits both the university and the construction industry. The results of this internship directly benefit the students in the OU program who receive more Revit instruction throughout the curriculum. Indirectly, industry benefits from hiring better trained graduates. Another benefit of this internship is the relationships built between industry and academia. As a 
result of this internship the faculty intern has a good working relationship with a local general contractor, namely JE Dunn Construction and the contractor has a good relationship with a professor in the program where they often recruit students.

The internship was beneficial to the faculty intern on more than one level. Not only did he or she gain valuable training in Autodesk Revit and is able to involve Revit projects in the curriculum, but the faculty intern also spent time on the construction site. The faculty intern witnessed the final stages of a large construction project. For example, all the building's mechanical and electrical systems were being tested as well as more simple items like testing the windows for water leaks. This real life construction experience cannot be duplicated.

Success in the construction industry today demands collaboration amongst a variety of team members such as constructors, engineers, architects, interior designers, lawyers, financiers, subcontractors, and owners. Construction faculty members often represent these diverse backgrounds. The AGC faculty internship programs can provide construction educators of diverse backgrounds as well as those with construction experience a method to either gain or supplement their construction experience. In this case it was used to learn Revit Structure, but it could be used to learn other specific skills such as new surveying techniques, materials, or lean construction practices. Simple exposure to construction practices, management styles, and daily routines on a job site are experiences that cannot be duplicated outside of the context of working on site that this internship provides.

\section{References}

1. Accreditation Board for Engineering and Technology (2013). Criteria for accrediting engineering technoloty programs.

2. American Council for Construction Education (2013). Standards and criteria for accreditation of postsecondary construction education programs. Document 103.

3. Associated General Contractors of America. (October 11, 2012). AGC Foundation posts 2013 Faculty Internship Application [WWW document]. URL http://news.agc.org/2012/10/11/agc-foundation-posts-2013-facultyinternship-application/

4. Associated Schools of Construction. (2012). Employment [WWW document]. URL http://www.ascweb.org/

5. Hynds, T. (2000). Professional development/internship opportunities for construction faculty: A win/win outcome. Journal of Construction Education, 5(2), 97-103.

6. McCuen, T. L. (2007). Industry experience: An important requirement for construction faculty. Associated Schools of Construction, Proceedings of the 43th Annual Conference, 2007.

7. Reginato, J. M. (2012). Education and construction industry experience desired of new construction management faculty. Associated Schools of Construction, Proceedings of the $46^{\text {th }}$ Annual Conference, 2010.

8. Shaurette, Mark. (2010). Faculty internship in demolition management: Advancing and reinforcing construction management education. Associated Schools of Construction, Proceedings of the $46^{\text {th }}$ Annual Conference, 2010. 